(c) American Dairy Science Association, 2004.

\title{
Fertility of Holstein Dairy Heifers after Synchronization of Ovulation and Timed Al or Al after Removed Tail Chalk
}

\author{
H. Rivera, H. Lopez, and P. M. Fricke \\ Department of Dairy Science, University of Wisconsin, Madison 53706
}

\section{ABSTRACT}

Nonlactating Holstein dairy heifers $(\mathrm{n}=352) 13 \mathrm{mo}$ of age were managed using a 42-d artificial insemination (AI) breeding period in which they received AI after removed tail chalk evaluated once daily. At AI breeding period onset ( $\mathrm{d} 0$ ), heifers were randomly assigned to receive synchronization of ovulation $(100 \mu \mathrm{g}$ of $\mathrm{GnRH}$, d 0; $25 \mathrm{mg}$ of $\mathrm{PGF}_{2 \alpha}, \mathrm{d} 6 ; 100 \mu \mathrm{g}$ of $\mathrm{GnRH}, \mathrm{d}$ 8) and timed AI (TAI; d 8) and AI after removed tail chalk for the entire AI breeding period (GPG; $\mathrm{n}=175)$, or AI after removed tail chalk for the entire AI breeding period (TC; $\mathrm{n}=177)$. As expected, $17.7 \%$ (31/175) of GPG heifers received AI after removed tail chalk before scheduled TAI. Pregnancy rate per artificial insemination (PR/AI) at $\sim 30 \mathrm{~d}$ after first AI tended to be greater for TC $(46.5 \%)$ than for GPG (38.3\%) heifers. No treatment $\times$ inseminator interaction was detected; however, overall PR/AI was low for heifers in both treatments due to variation among the 3 inseminators $(24.8,30.0$, and 58.0\%). Pregnancy loss from $\sim 30$ to $\sim 75 \mathrm{~d}$ after first AI was $10 \%$ and did not differ between treatments. Based on survival analysis, days to first AI was greater for TC than for GPG heifers, whereas days to pregnancy across the 42$\mathrm{d}$ AI breeding period did not differ between treatments. Overall, $81.2 \%$ of GPG heifers receiving TAI synchronized luteal regression and ovulated within $48 \mathrm{~h}$ after the second GnRH injection. We conclude that this synchronization protocol can yield acceptable fertility in dairy heifers if AI to estrus is conducted between treatment with $\mathrm{GnRH}$ and $\mathrm{PGF}_{2 \alpha}$ and $\mathrm{AI}$ efficiency is optimized.

(Key words: dairy heifer, synchronization of ovulation, timed artificial insemination)

Abbreviation key: $\mathbf{P R} / \mathbf{A I}=$ pregnancy rate per artificial insemination, $\mathbf{P}_{\mathbf{4}}=$ progesterone, $\mathbf{T A I}=$ timed artificial insemination, WHI = wither height index.

Received November 5, 2003.

Accepted January 3, 2004.

Corresponding author: P. M. Fricke; e-mail: pmfricke@wisc.edu.

\section{INTRODUCTION}

Many estrus synchronization protocols have been developed for cattle using progestogens, $\mathrm{PGF}_{2 \alpha}$ (or $\mathrm{PGF}_{2 \alpha}$ analogs), and estrogens alone or in various combinations to control the physiology of the reproductive cycle and synchronize estrus (Odde, 1990). The primary reason for synchronizing estrus in dairy heifers is to facilitate use of $\mathrm{AI}$ (Xu and Burton, 1999). The effectiveness of current estrus synchronization strategies for heifers is limited because dairy producers must rely on visual estrus detection, which is inefficient on most farms, to accurately time AI. In support of this notion, results from a nationwide survey of US dairy producers identified "inadequate heat detection for AI" and "lack of time to supervise AI" as 2 important reasons for not using AI to breed dairy heifers (Erven and Arbaugh, 1987).

Ovsynch was the first protocol developed to successfully synchronize ovulation in lactating dairy cows, thereby allowing for timed artificial insemination (TAI; Pursley et al., 1995). Unfortunately, dairy heifers respond poorly to Ovsynch and TAI, yielding conception rates 20 to $40 \%$ lower than heifers receiving AI to a detected estrus (Schmitt et al., 1996; Pursley et al., 1997). Some studies have assessed the effectiveness of synchronizing ovulation using $\mathrm{GnRH}$ and $\mathrm{PGF}_{2 \alpha}$ followed by TAI in dairy heifers, but results are inconsistent due to low numbers of heifers (Moreira et al., 2000a) or an unknown synchronization response (Pursley et al., 1997). Moreover, previous experiments have tested TAI protocols in dairy heifers using a 7-d interval between $\mathrm{GnRH}$ and $\mathrm{PGF}_{2 \alpha}$ (Pursley et al., 1997; Moreira et al., 2000a; Lucy et al., 2001).

The objective of this study was to compare the effectiveness of a synchronization protocol using GnRH and $\mathrm{PGF}_{2 \alpha}$ followed by TAI to a standard reproductive management system using AI after removed tail chalk in a commercial dairy heifer growing operation in Wiscon$\sin$. Our hypothesis was that synchronization of ovulation in dairy heifers using $\mathrm{GnRH}$ and $\mathrm{PGF}_{2 \alpha}$ followed by TAI would result in improved reproductive performance compared with herd mates managed using AI after removed tail chalk, the standard reproductive management system in place on this farm. Secondary objectives were to assess ovarian responses to the GPG protocol 
and fertility and embryonic losses in dairy heifers under field conditions.

\section{MATERIALS AND METHODS}

\section{Facilities and Management of Heifers}

This field trial was conducted on a custom dairy heifer growing operation located in central Wisconsin comprising approximately 4500 Holstein dairy heifers. Heifers from 11 different farms arrived at the custom heifer growing operation at around 5 mo of age and were sorted by age to different pens and managed until 13 mo of age in open dry lots throughout the year. Every 10 to $14 \mathrm{~d}$, a group of 80 to 100 heifers within 2 wk of turning 13 mo of age was moved to one of $4 \mathrm{AI}$ breeding pens, each with 100 self-locking head gates. Heifers were fed a TMR based on corn silage, alfalfa haylage, potatoes, and mineral mix once daily between 0630 and $1100 \mathrm{~h}$ throughout the AI breeding period. Artificial insemination was conducted for a 42 -d period based on removed tail chalk, which was applied and evaluated daily during the morning feeding period after heifers were restrained in the self-locking head gates. After this 42-d AI breeding period, heifers were moved to a dry lot with 2 natural service bulls for about 2 mo. For each group of heifers, pregnancy status was evaluated via palpation per rectum by the herd veterinarian around $60 \mathrm{~d}$ after leaving the $\mathrm{AI}$ breeding pen to confirm all pregnancies greater than $60 \mathrm{~d}$ (AI pregnancies) based on breeding dates and stage of gestation estimated by the veterinarian at the pregnancy diagnosis. Any pregnancies estimated to be less than $60 \mathrm{~d}$ were attributed to the natural service bulls. Pregnant heifers stayed in dry lots with natural service bulls and were returned to their farm of origin 6 to 8 wk before their expected calving date. Heifers failing to conceive were culled based on individual owner decision after arrival at their herd of origin.

\section{Treatments}

This experiment was conducted in 4 replicates $(\mathrm{n}=$ $\sim 88$ heifers/replicate) initiated from May 21 to August 13, 2002. At AI breeding period onset (d 0), heifers were randomly assigned to receive either synchronization of ovulation using GnRH (Cystorelin; Merial Ltd; Duluth, GA) and $\mathrm{PGF}_{2 \alpha}$ (Lutalyse; Pharmacia Animal Health, Kalamazoo, MI) and TAI (100 $\mu \mathrm{g}$ of $\mathrm{GnRH}, \mathrm{d} 0 ; 25 \mathrm{mg}$ of $\mathrm{PGF}_{2 \alpha}, \mathrm{d} 6 ; 100 \mu \mathrm{g}$ of GnRH+TAI, d 8) followed by $\mathrm{AI}$ after removed tail chalk for the remainder of the AI breeding period (GPG; $\mathrm{n}=175$ ), or AI after removed tail chalk for the entire AI breeding period (TC; $\mathrm{n}=$ 177). All GPG heifers that did not receive AI to removed tail chalk during the protocol received TAI immediately after the second GnRH injection (e.g., Cosynch), which was administered $48 \mathrm{~h}$ after treatment with $\mathrm{PGF}_{2 \alpha}$. Any GPG heifer detected in estrus before scheduled TAI on d 8 received AI after removed tail chalk, and the synchronization protocol was discontinued. Artificial insemination was performed by 3 herd personnel (the herd manager and 2 full-time employees). A maximum of 39 TAI were performed for GPG heifers on $\mathrm{d} 8$ of the experiment for each replicate.

\section{Blood Sampling and Radioimmunoassay}

Blood samples were collected from GPG heifers via venipuncture of the median caudal vein or artery near the base of the tail just before administration of each injection and on the day of AI after removed tail chalk from all heifers regardless of treatment during the first $8 \mathrm{~d}$ of the experiment. Blood samples were allowed to clot for $24 \mathrm{~h}$ at $4^{\circ} \mathrm{C}$, centrifuged (3000 rpm for $15 \mathrm{~min}$ ), and serum was harvested and stored at $-20^{\circ} \mathrm{C}$ until assayed for progesterone $\left(\mathbf{P}_{4}\right)$ concentration by radioimmunoassay (Coat-a-Count Progesterone, Diagnostic Products Corporation, Los Angeles, CA). Inter- and intraassay coefficients of variation were 5.7 and $6.9 \%$, respectively.

\section{Progesterone Classes}

All GPG heifers were assigned to $\mathrm{P}_{4}$ classes based on $\mathrm{P}_{4}$ concentrations in serum samples collected just before treatment with the first GnRH injection (d 0), treatment with $\mathrm{PGF}_{2 \alpha}(\mathrm{d} 6)$ and treatment with the second $\mathrm{GnRH}$ injection (d 8) as described by Cordoba and Fricke (2002) with the following modifications. For samples collected just before the first 2 injections, serum samples were classified as either low $(\mathrm{L} ; \leq 1.0 \mathrm{ng} / \mathrm{mL})$ or high $(\mathrm{H} ;>1.0 \mathrm{ng} / \mathrm{mL})$ at the time of each injection. For serum samples collected on $d 8$, a decrease of $60 \%$ or more of the $\mathrm{P}_{4}$ concentration at treatment with $\mathrm{PGF}_{2 \alpha}$ by $48 \mathrm{~h}$ after treatment was additionally considered to define low $\mathrm{P}_{4}$. This second criterion for defining low $\mathrm{P}_{4}$ on d 8 was included based on a preliminary study in which $\mathrm{P}_{4}$ was measured after induced luteolysis in heifers using $\mathrm{PGF}_{2 \alpha}$ preceded $6 \mathrm{~d}$ by GnRH (Rivera and Fricke, 2002).

This classification system resulted in 8 possible $\mathrm{P}_{4}$ class permutations for GPG heifers: HHH, HHL, HLH, HLL, LHH, LHL, LLH, and LLL. Only $(82 \%, 144 / 175)$ of GPG heifers were assigned to $\mathrm{P}_{4}$ classes because blood sampling was discontinued for the 31 heifers receiving AI after removed tail chalk before scheduled TAI (Table 1). The $\mathrm{P}_{4}$ classes were used to estimate the stage of the cycle at initiation of GPG, response to the first $\mathrm{GnRH}$ injection, and luteolysis in response to 
Table 1. Reproductive parameters for GPG heifers receiving timed AI based on progesterone $\left(\mathrm{P}_{4}\right)$ concentrations of blood samples collected immediately before each injection of the synchronization protocol.

\begin{tabular}{|c|c|c|c|c|c|c|}
\hline $\mathrm{P}_{4}$ Class $^{1}$ & $\mathrm{n}$ & $\begin{array}{l}\text { CL } \\
\text { regression }{ }^{2} \mathrm{n} \\
(\%)\end{array}$ & $\begin{array}{l}\text { Ovulation } \\
\text { after 2nd } \\
\mathrm{GnRH}^{3} \\
\mathrm{n}(\%)\end{array}$ & $\begin{array}{l}\text { Synchronization } \\
\text { rate }^{4} \\
\text { n }(\%)\end{array}$ & $\begin{array}{l}\mathrm{PR} / \mathrm{AI}^{5} \\
\mathrm{n}(\%)\end{array}$ & $\begin{array}{l}\text { Pregnancy } \\
\operatorname{loss}^{6} \\
\text { n }(\%)\end{array}$ \\
\hline \multicolumn{7}{|c|}{ High $\mathrm{P}_{4}$ on $\mathrm{d} 8$} \\
\hline $\mathrm{HHH}$ & 3 & $0(0.0)$ & $2(66.7)$ & $0(0.0)$ & $1(33.3)$ & $0(0.0)$ \\
\hline LHH & 1 & $0(0.0)$ & $1(100.0)$ & $0(0.0)$ & $0(0.0)$ & $0(0.0)$ \\
\hline $\mathrm{HLH}$ & 0 & - & - & - & - & - \\
\hline LLH & 0 & - & - & - & - & - \\
\hline Total & 4 & $0(0.0)$ & $3(75.0)$ & $0(0.0)$ & $1(25.0)$ & $0(0.0)$ \\
\hline \multicolumn{7}{|c|}{ Low $\mathrm{P}_{4}$ on $\mathrm{d} 8$} \\
\hline LLL & 0 & - & - & - & - & - \\
\hline HLL & 12 & - & $11(91.6)$ & $0(0.0)$ & $4(33.3)$ & $0(0.0)$ \\
\hline LHL & 34 & $34(100.0)$ & $32(94.1)$ & $32(94.1)$ & $11(32.3)$ & $2(18.2)$ \\
\hline HHL & 94 & $94(100.0)$ & $85(90.4)$ & $85(90.4)$ & $39(41.5)$ & $3(7.7)$ \\
\hline Total & 140 & $128(91.4)$ & $128(91.4)$ & $117(83.6)$ & $54(38.6)$ & $5(9.3)$ \\
\hline Overall & 144 & 128 (88.9) & $131(91.0)$ & $117(81.2)$ & $55(38.2)$ & $5(9.0)$ \\
\hline
\end{tabular}

${ }^{1}$ Combinations of highs $(\mathrm{H} ;>1 \mathrm{ng} / \mathrm{mL})$ and lows $(\mathrm{L} ; \leq 1 \mathrm{ng} / \mathrm{mL})$ represent serum progesterone $\left(\mathrm{P}_{4}\right)$ concentration at the first GnRH injection (d 0), the $\mathrm{PGF}_{2 \alpha}$ injection (d 6), and the second GnRH injection (d 8) of the GPG protocol.

${ }^{2} \mathrm{CL}$ regression was considered to occur when serum $\mathrm{P}_{4}$ concentration decreased to $\leq 1 \mathrm{ng} / \mathrm{mL}$ or there was a decrease of $60 \%$ or more of the $\mathrm{P}_{4}$ concentration at treatment with $\mathrm{PGF}_{2 \alpha}$ by $48 \mathrm{~h}$ after treatment.

${ }^{3}$ Number of heifers that ovulated at least one follicle by $48 \mathrm{~h}$ after the second GnRH injection expressed as a percentage of heifers receiving the GPG protocol. Double ovulation rate was 5\% (7/131).

${ }^{4}$ Number of heifers with low $\mathrm{P}_{4}$ on $\mathrm{d} 8$ and in which a follicle ovulated within $48 \mathrm{~h}$ of the second $\mathrm{GnRH}$ injection expressed as a percentage of heifers receiving the GPG protocol.

${ }^{5}$ Proportion of heifers diagnosed pregnant at $30 \mathrm{~d}$ after TAI.

${ }^{6}$ Proportion of heifers diagnosed pregnant $30 \mathrm{~d}$ after TAI that were diagnosed nonpregnant $75 \mathrm{~d}$ after TAI.

$\mathrm{PGF}_{2 \alpha}$ for heifers receiving the GPG protocol similar to the methods described by Moreira et al. (2001) and Cordoba and Fricke (2002).

\section{Ultrasonography}

To assess ovulatory response to the second GnRH injection of the GPG protocol, ovarian structures were monitored at the time of the second GnRH injection and $48 \mathrm{~h}$ thereafter for heifers in the GPG group receiving TAI by using an ultrasound machine equipped with a transrectal $7.5 \mathrm{MHz}$ linear-array transducer (Aloka 500V; Corometrics Medical Systems, Inc., Wallingford, CT). Ultrasound examinations were not conducted for GPG heifers that received AI after removed tail chalk before scheduled TAI or for TC heifers. During each ultrasound examination, a sketch of the location and diameter of all ovarian structures $\geq 8 \mathrm{~mm}$ in diameter was recorded. For each ovarian structure, 2 diameter measurements taken at right angles were recorded on a single frozen image of the apparent maximal diameter of the structure using the digital calipers of the ultrasound machine, and diameters were calculated as the mean of these 2 measurements. Ovulatory response after the second GnRH injection was determined by the presence of one or more dominant follicles at the time of the second GnRH injection and the absence of one (single ovulation) or 2 (double ovulation) of those follicles at an ultrasound examination conducted $48 \mathrm{~h}$ later (Fricke et al., 1998).

Heifers with a serum $\mathrm{P}_{4}$ concentration $>1 \mathrm{ng} / \mathrm{mL}$ just before treatment with $\mathrm{PGF}_{2 \alpha}$ were considered to have a functional CL. Luteal regression was considered to occur when serum $\mathrm{P}_{4}$ concentration decreased to $\leq 1$ $\mathrm{ng} / \mathrm{mL}$ or there was a decrease of $60 \%$ or more of the $\mathrm{P}_{4}$ concentration at treatment with $\mathrm{PGF}_{2 \alpha}$ by $48 \mathrm{~h}$ after treatment. Double ovulation rate was calculated as the number of heifers that ovulated 2 follicles within $48 \mathrm{~h}$ of the second GnRH injection and expressed as percentage of heifers that ovulated after the second $\mathrm{GnRH}$ injection. Synchronization rate was defined as the proportion of heifers that underwent luteal regression $\left(\mathrm{P}_{4}\right.$ $<1.0 \mathrm{ng} / \mathrm{mL}$ or $60 \%$ reduction as described previously) by the second $\mathrm{GnRH}$ injection and in which ovulation occurred by $48 \mathrm{~h}$ after the second GnRH injection expressed as percentage of the total number of heifers receiving the protocol.

\section{Pregnancy Rate per Artificial Insemination}

Pregnancy status was determined 30 and $75 \mathrm{~d}$ after d 8 of the experiment (i.e., the day that GPG heifers 
received TAI) using transrectal ultrasonography. Due to variation in the interval from the start of the experiment to first AI among TC heifers, mean ( \pm SEM) interval for all heifers from first insemination to pregnancy diagnosis was $31.5 \pm 0.1$ and $74.5 \pm 0.3 \mathrm{~d}$ after first AI. Visualization of a fluid-filled uterine horn and the presence of a conceptus were used as positive indicators of pregnancy (Fricke et al., 1998). Pregnancy rate per artificial insemination $(\mathbf{P R} / \mathbf{A I})$ to first $\mathrm{AI}$ at $31.5 \pm 0.1$ and $74.5 \pm 0.3 \mathrm{~d}$ after $\mathrm{AI}$ and pregnancy loss between these 2 stages were calculated for heifers in both treatments. Cumulative pregnancy rate for all AI during the breeding period also was calculated for all heifers in both treatments. Fetal sex was determined for all pregnant heifers at the ultrasound examination conducted on $\mathrm{d} 74.5 \pm 0.3$ of gestation based on location of the genital tubercle. A fetus was recorded as a male when the genital tubercle was located in the area caudal to the umbilicus and a female when located beneath the tail (Curran and Ginther, 1991).

\section{Body Size Parameters}

Body condition score was assigned to each heifer at first AI by the same individual throughout the experiment using a quarter-point scale from 1 to 5 , where $1=$ emaciated and 5 = obese (Ferguson et al., 1994). Live BW was estimated for each heifer at first AI using a commercial dairy tape (Weight-By-Breed Dairy Cow Tape; Nasco, Fort Atkinson, WI), and hip height and wither height were measured for each heifer at first AI on a level concrete surface with the heifer in a normal standing position. Wither height index (WHI) was calculated as BW divided by wither height as described by Looper and Bethard (2000), but using metric rather than Imperial units of measure.

\section{Statistical Analyses}

Categorical variables (ovulatory response after GnRH and PR/AI) were analyzed by multifactorial logistic regression using the LOGISTIC procedure of SAS (SAS, 1999). The model used to analyze PR/AI to first $\mathrm{AI}$ included treatment, inseminator, replicate, and the interaction of treatment $\times$ inseminator, with BCS, wither height, hip height, and BW at first AI as regression variables. Because all heifers within a replicate were turning 13 mo of age within a 2 -wk period, age was not included in this model. Continuous variables (days to first AI, days to conception, follicular diameter) were analyzed using the GLM procedure of SAS. Survival analysis (i.e., failure time analysis) was used to assess the effect of treatment on time to first $\mathrm{AI}$ and time to pregnancy by using the Log-Rank method of the LIFETEST procedure of SAS. Observations from heifers that were not inseminated (for analysis of time to first AI) or failed to become pregnant (for analysis of time to pregnancy) during the AI breeding period were considered as censored. For all analyses, a significant difference was considered to occur when $P \leq 0.05$, whereas a statistical tendency was considered to occur when $P>0.05$ and $\leq 0.15$.

\section{RESULTS AND DISCUSSION}

\section{Accuracy of Detection of Estrus}

To evaluate the accuracy of the tail chalk system for detection of estrus and to determine the proportion of GPG heifers not in estrus when receiving AI after removed tail chalk before scheduled TAI, blood samples were collected from heifers on the day of AI regardless of treatment during the first $8 \mathrm{~d}$ of the experiment. It was assumed that heifers with low $\mathrm{P}_{4}$ were likely in estrus; however, it is possible that some heifers had low $\mathrm{P}_{4}$ and were not in estrus (i.e., anovulatory animals). Nevertheless, our objective was to determine the proportion of heifers that were not in estrus at the time of insemination (i.e., high $\mathrm{P}_{4}$ at $\mathrm{AI}$ ). Only $8.2 \%$ of heifers receiving $\mathrm{AI}$ had a serum $\mathrm{P}_{4}$ concentration $\geq 1 \mathrm{ng} / \mathrm{mL}$ on the day of AI, whereas $91.8 \%$ of heifers had a serum $\mathrm{P}_{4}$ concentration $<1 \mathrm{ng} / \mathrm{mL}$ on the day of AI (Table 2). No heifers with high $\mathrm{P}_{4}$ on the day of AI were pregnant $\sim 30 \mathrm{~d}$ after that service, whereas heifers with low $\mathrm{P}_{4}$ on the day of AI had a PR/AI at $~ 30 \mathrm{~d}$ after AI similar to that of the 172 heifers receiving AI after removed tail chalk (Tables 2 and 3).

Although the correct timing of AI cannot definitively be established for heifers with low $\mathrm{P}_{4}$ on the day of AI, these heifers were inseminated in the absence of a functional CL, a stage of the cycle when estrus and ovulation would normally occur. By contrast, heifers with high $\mathrm{P}_{4}$ on the day of AI had a functional CL at $\mathrm{AI}$ and were inseminated at an incorrect stage of the cycle. Thus, use of tail chalk in the present study was an effective method for estrus detection for first AI resulting in an overall accuracy of $91.8 \%$. Cordoba and Fricke (2002) reported an $84 \%$ submission rate to first AI during a 23-d AI breeding period using a tail paint system in lactating dairy cows managed in a grazingbased system, and Macmillan et al. (1988) reported a 95\% submission rate using a similar tail painting system in heifers after synchronized estrus.

\section{Effect of Treatment on PR/AI}

Overall PR/AI to first AI for all heifers in the present study was $42.4 \%$ (147/347) and, although PR/AI did not differ statistically between treatments, PR/AI tended 
Table 2. Accuracy of timing of artificial insemination and pregnancy rate per artificial insemination (PR/ $\mathrm{AI})$ during the first $8 \mathrm{~d}$ of the $\mathrm{AI}$ breeding period for Holstein dairy heifers in both treatments receiving $\mathrm{AI}$ after removed tail chalk.

\begin{tabular}{|c|c|c|c|c|}
\hline \multirow[b]{2}{*}{ Day } & \multirow[b]{2}{*}{$\begin{array}{l}\text { Heifers } \\
\text { inseminated }\end{array}$} & \multicolumn{2}{|c|}{ Progesterone status ${ }^{1}$ at AI } & \multirow[b]{2}{*}{$\begin{array}{l}\text { Accuracy }{ }^{2} \\
\%\end{array}$} \\
\hline & & $\begin{array}{l}\text { High } \\
\mathrm{n}(\mathrm{PR} / \mathrm{AI}, \%)^{1}\end{array}$ & $\begin{array}{l}\text { Low } \\
\text { n (PR/AI, \%) }\end{array}$ & \\
\hline 1 & 18 & $1(0.0)$ & $17(29.4)$ & 94.4 \\
\hline 2 & 7 & $0(0.0)$ & 7 (57.1) & 100.0 \\
\hline 3 & 9 & $2(0.0)$ & $7(29.4)$ & 77.8 \\
\hline 4 & 3 & $0(0.0)$ & $3(0.0)$ & 100.0 \\
\hline 5 & 15 & $2(0.0)$ & $13(53.8)$ & 86.7 \\
\hline 6 & 14 & $0(0.0)$ & $14(42.8)$ & 100.0 \\
\hline 7 & 20 & $2(0.0)$ & 18 (61.1) & 90.0 \\
\hline 8 & 11 & $1(0.0)$ & $10(40.0)$ & 90.9 \\
\hline Overall & 97 & $8(0.0)$ & $89(44.9)$ & 91.8 \\
\hline
\end{tabular}

\footnotetext{
${ }^{1}$ Serum progesterone concentration of blood samples collected on the day of AI was classified as either
} high (> $1 \mathrm{ng} / \mathrm{mL})$ or low $(\leq 1 \mathrm{ng} / \mathrm{mL})$.

${ }^{2}$ Proportion of heifers receiving AI that had low serum $\mathrm{P}_{4}$ concentration on the day of AI.

to be greater $(P=0.12)$ for TC than for GPG heifers (Table 3). One factor explaining the tendency for a lower PR/AI in GPG heifers may be due to the proportion of GPG heifers that ovulated a follicle after the second GnRH injection. Studies in which ovulation rate after the second GnRH injection of Ovsynch was assessed in lactating dairy cows using a similar technique were 87\% (Vasconcelos et al., 1999) and 84\% (Fricke et al., 1998). In the present study, ovulation rate after the second GnRH injection for heifers receiving TAI was $91.0 \%$ (Table 1). It is important to note that this figure does not include the 31 heifers that received AI based on removed tail chalk before TAI. Ovulation rate after the second GnRH injection would have decreased dramatically had these heifers not been detected in estrus during the protocol, and this is likely the reason that heifers respond poorly to Ovsynch when managed as a TAI protocol without detection of estrus (Pursley et al., 1997). Adjusting the PR/AI of $38.2 \%$ (55/144) for all GPG heifers in the present study to include only the 131 heifers that ovulated after the second GnRH injection would increase PR/AI to $42.0 \%$ (55/131, Table 1), a PR/

Table 3. Effect of treatment on pregnancy rate per artificial insemination (PR/AI), pregnancy loss, and cumulative pregnancy rate of Holstein dairy heifers during the 42-d AI breeding period.

\begin{tabular}{|c|c|c|c|}
\hline \multirow[b]{2}{*}{ Item } & \multicolumn{2}{|c|}{ Treatment } & \multirow[b]{2}{*}{$P$-value } \\
\hline & $\mathrm{TC}$ & GPG & \\
\hline \multicolumn{4}{|c|}{$\mathrm{PR} / \mathrm{AI}$ to 1 st $\mathrm{AI}$ at $30 \mathrm{~d}$ after $\mathrm{TAI}^{1}$} \\
\hline $\begin{array}{l}\text { Overall, \% } \\
\text { (no./no.) }\end{array}$ & $\begin{array}{l}46.5 \\
(80 / 172)\end{array}$ & $\begin{array}{l}38.3 \\
(67 / 175)\end{array}$ & 0.12 \\
\hline $\begin{array}{l}\text { After TAI, \% } \\
\text { (no./no.) }\end{array}$ & - & $\begin{array}{l}38.2 \\
(55 / 144)\end{array}$ & - \\
\hline $\begin{array}{l}\text { After removed tail chalk, \% } \\
\text { (no./no.) }\end{array}$ & $\begin{array}{l}46.5 \\
(80 / 172)\end{array}$ & $\begin{array}{l}38.7 \\
(12 / 31)\end{array}$ & 0.44 \\
\hline \multicolumn{4}{|l|}{ PR/AI to first $\mathrm{AI}$ at $75 \mathrm{~d}^{1}$} \\
\hline $\begin{array}{l}\text { Overall, \% } \\
\text { (no./no.) }\end{array}$ & $\begin{array}{l}41.9 \\
(72 / 172)\end{array}$ & $\begin{array}{l}34.3 \\
(60 / 175)\end{array}$ & 0.15 \\
\hline \multicolumn{4}{|l|}{ Pregnancy loss, 30 to $75 \mathrm{~d}^{1}$} \\
\hline $\begin{array}{l}\text { Overall, \% } \\
\text { (no./no.) }\end{array}$ & $\begin{array}{l}10.0 \\
(8 / 80)\end{array}$ & $\begin{array}{l}10.4 \\
(7 / 67)\end{array}$ & 0.98 \\
\hline \multicolumn{4}{|c|}{$\mathrm{PR} / \mathrm{AI}$ to $2 \mathrm{nd}$ and $3 \mathrm{rd} \mathrm{AI}$ at 41 to $66 \mathrm{~d}$ after $\mathrm{AI}$} \\
\hline $\begin{array}{l}\text { Overall, \% } \\
\text { (no./no.) }\end{array}$ & $\begin{array}{l}34.0 \\
(31 / 91)\end{array}$ & $\begin{array}{l}42.1 \\
(51 / 121)\end{array}$ & 0.25 \\
\hline \multicolumn{4}{|l|}{ Cumulative pregnancy rate $^{2}$} \\
\hline $\begin{array}{l}\text { Overall, \% } \\
\text { (no./no.) }\end{array}$ & $\begin{array}{l}58.2 \\
(103 / 177)\end{array}$ & $\begin{array}{l}63.4 \\
(111 / 175)\end{array}$ & 0.38 \\
\hline
\end{tabular}

${ }^{1}$ Due to variation in the interval from the start of the experiment to first AI among TC heifers, mean $( \pm$ SEM) interval for all heifers from first insemination to pregnancy diagnosis was $31.5 \pm 0.1$ and $74.5 \pm 0.3$ d after first AI.

${ }^{2}$ Proportion of heifers diagnosed pregnant to AI during the 42-d AI breeding period. 
AI similar to that observed for TC heifers $(46.5 \%$, Table 3 ).

Pregnancy loss contributes to reproductive inefficiency in cattle because fertility assessed at any point during pregnancy is a function of both conception rate and pregnancy loss (Fricke, 2002). Fertilization rate after AI in beef cows is $90 \%$, whereas embryonic survival is $93 \%$ by d 8 and only $56 \%$ by d 12 after AI (Diskin and Sreenan, 1980). Reported pregnancy losses in lactating dairy cows are greater than that in dairy heifers (20 vs. 5\%; Smith and Stevenson, 1995). The 10.2\% pregnancy loss in the present study is greater than that reported by Smith and Stevenson (1995) but less than the 20.5\% (Smith and Stevenson, 1995) and the 13.5\% (Fricke et al., 1998) reported during a comparable stage of pregnancy in lactating dairy cows.

Follicles in lactating dairy cows achieve ovulatory capacity around $10 \mathrm{~mm}$ in diameter (Sartori et al., 2001). For GPG heifers in the present study, diameter of the largest follicle at the time of the second GnRH injection affected ovulatory response. Follicle diameter at GnRH was greater $(P<0.01)$ for follicles that went on to ovulate by $48 \mathrm{~h}$ after the second $\mathrm{GnRH}$ injection than for follicles failing to ovulate $(13.2 \pm 0.2$ vs. 10.2 $\pm 0.8 \mathrm{~mm}$, respectively). By contrast, follicle size at the time of the second GnRH injection did not differ $(P=$ 0.37) among GPG heifers based on pregnancy status assessed $30 \mathrm{~d}$ after TAI.

\section{Effect of Inseminator on PR/AI}

The overall PR/AI of $42.4 \%$ for the 347 heifers receiving $\mathrm{AI}$ in the present study was lower than expected. Although fertility of dairy heifers is consistently higher than that of lactating dairy cows (Ron et al., 1984), the reported PR/AI for dairy heifers varies widely among studies. Fertility of heifers receiving AI at standing estrus was reported to be 47 (Donovan et al., 2003), 59 (Gwazdauskas et al., 1981), 55 to 66 (Butler and Smith, 1989), and 74\% (Pursley et al., 1997). One reason for the poor overall PR/AI in the present study was the poor performance of 2 of the 3 herd inseminators that conducted AI throughout the study (Table 4). Most herd-level variation in conception rate among heifers is due to variation among inseminators (Ron et al., 1984). Barth (1993) reported that timing of AI, semen quality, semen handling, and inseminator expertise influenced fertility to AI in cattle. Improper semen placement in the reproductive tract also affects fertility to AI with over half of inseminators evaluated depositing semen into the cervix rather than correctly placing it into the uterine body (López-Gatius, 1999). A common mistake was for inseminators to deposit semen in the cervix while withdrawing the pipette or straw during AI (Zavy and Geisert, 1994).

When PR/AI for the 3 inseminators in the present study was compared, the 2 herd employees had PR/AI of 24.8 and $30.0 \%$ (inseminators 1 and 2, respectively), which were lower $(P<0.01)$ than that of the herd manager (inseminator 3 ) who had a PR/AI of $58.0 \%$ (Table 4). No treatment $x$ inseminator interaction was detected $(P=0.70)$, indicating that treatment effects on $\mathrm{PR} / \mathrm{AI}$ in the present study were not confounded by the inseminator effect. A similar effect of AI technician on conception rate has been reported for beef heifers synchronized using melengestrol acetate and $\mathrm{PGF}_{2 \alpha}$ (Salverson et al., 2001). Had the herd manager inseminated all heifers in the present experiment, PR/AI would have been acceptable based on previous reports in dairy heifers (Gwazdauskas et al., 1981; Butler and Smith, 1989).

\section{Reproductive Performance During the Al Breeding Period}

Research has consistently supported that lifetime milk yield, 305-d lactation yield, and lifetime profit of replacement heifers are maximized when heifers calve for the first time between 23 and 25 mo of age (Heinrichs, 1993; Van Amburgh et al., 1998) and weigh around $560 \mathrm{~kg}$ after calving (Hoffman, 1997; Looper and Bethard, 2000). Age at first breeding coupled with reproductive efficiency to first and subsequent breedings determine average age at first calving and, more important, the variation in age at first calving among similar-aged heifers in a breeding group (Fricke, 2003). In the present study, GPG heifers were synchronized and received first AI by d 8 of the AI breeding period. This strategy not only increases the AI service rate and groups heifers to conceive more uniformly at the onset of the breeding period, but also concentrates expression of return estrus for heifers failing to conceive to first AI (see Figure 2).

As expected, 17.7\% (31/175) of GPG heifers received AI after removed tail chalk before scheduled TAI (Table 3 ; Figures 1 and 2). Two of these heifers had high $\mathrm{P}_{4}$ on the day of AI; therefore, the proportion of heifers correctly identified in estrus before TAI was $17.0 \%$ (29/ 175), and these heifers received AI on d $5.3 \pm 0.2$ of the AI breeding period. In 2 previous reports, $17 \%$ of randomly cycling dairy (Rivera and Fricke, 2002) and beef (Roy and Twagiramungu, 1996) heifers expressed estrus during a similar synchronization protocol as that tested in the present study. These heifers likely received the first GnRH injection during late diestrus or early proestrus (i.e., d 14 to 18) and failed to synchronize in a similar physiologic scenario as described in detail by Cordoba and Fricke (2002) for lactating cows receiv- 
Table 4. Effect of inseminator on pregnancy rate per artificial insemination (PR/AI) of Holstein dairy heifers receiving AI after removed tail chalk (TC) or synchronization of ovulation and timed artificial insemination (GPG).

\begin{tabular}{llll}
\hline & \multicolumn{3}{c}{ Inseminator } \\
\cline { 2 - 4 } Treatment & 1 & 2 & 3 \\
\hline TC, \% & 30.2 & 33.3 & 62.6 \\
(no./no.) & $(16 / 53)$ & $(12 / 36)$ & $(52 / 83)$ \\
GPG, \% & 20.0 & 25.0 & 53.8 \\
(no./no.) & $(12 / 60)$ & $(6 / 24)$ & $(49 / 91)$ \\
Overall, \% & $24.8^{\mathrm{a}}$ & $30.0^{\mathrm{a}}$ & $58.0^{\mathrm{b}}$ \\
(no./no.) & $(28 / 113)$ & $(18 / 60)$ & $(101 / 174)$ \\
\hline
\end{tabular}

${ }^{\mathrm{a}, \mathrm{b}}$ Within a row, percentages with different superscripts differ $(P<0.01)$. Treatment by inseminator interaction was not significant $(P=0.70)$.

ing Ovsynch. The proportions of dairy heifers with 2, 3 , and 4 follicular waves were 56,33 , and $11 \%$, respectively (Sartori et al., 2004), indicating that nearly half of dairy heifers have more than 2 follicular waves per estrous cycle. In a previous study, all dairy heifers ini-
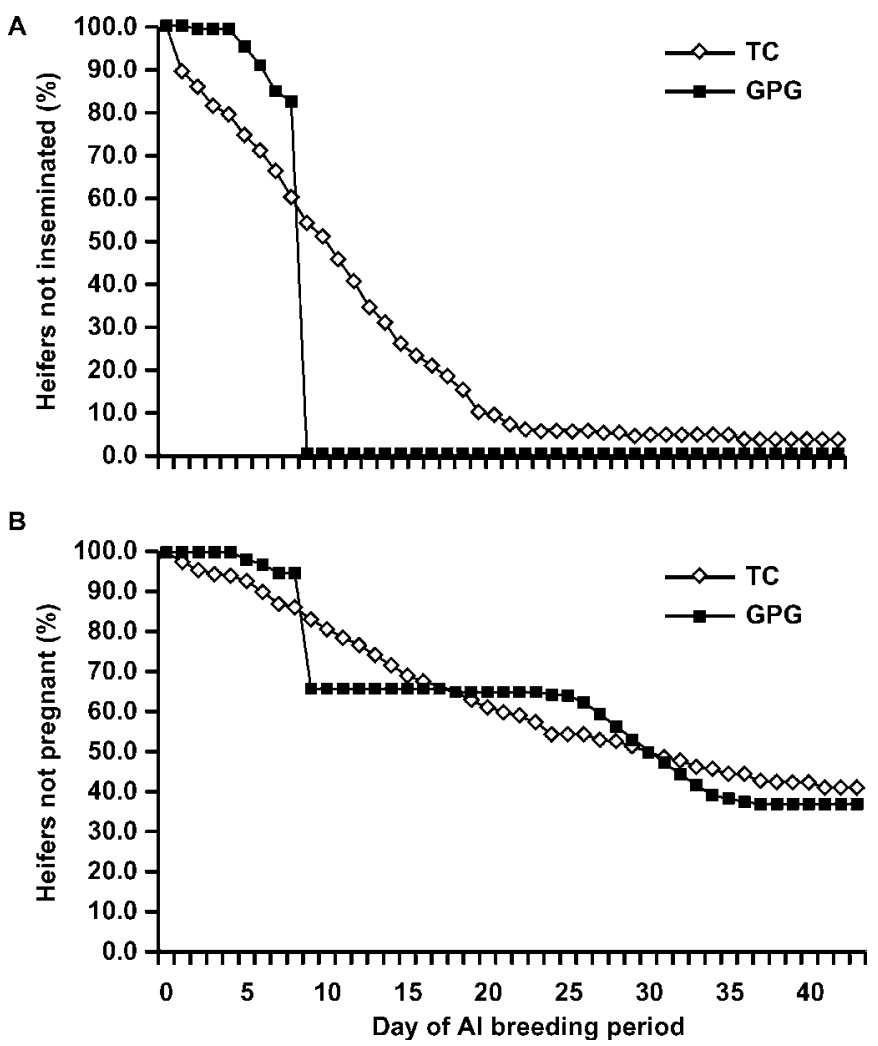

Figure 1. Effect of treatment on survival to first AI service (upper panel) and survival to pregnancy (lower panel) during the 42-d AI breeding period. Heifers were randomly assigned to receive either synchronization of ovulation and timed $\mathrm{AI}$ and $\mathrm{AI}$ after removed tail chalk for the entire AI breeding period (GPG; $\mathrm{n}=175$ ), or AI after removed tail chalk for the entire AI breeding period (TC; $\mathrm{n}=177$ ). A treatment effect $(P<0.01)$ was detected for $d$ to first AI service (upper panel), whereas treatment did not affect $d$ to pregnancy (lower panel). tiating Ovsynch on d 15 of the estrous cycle were observed in estrus before the second GnRH injection, whereas estrus behavior was not observed when the protocol was initiated on $\mathrm{d} 2,5,10$, or 18 of the cycle (Moreira et al., 2000a). For heifers exhibiting 3 follicular waves, the later stage of the cycle coincides with emergence of the third follicular wave (Ginther et al., 1996) when the dominant follicle of the second wave has lost ovulatory capacity and a follicle from the third wave has not yet undergone deviation and acquired ovulatory capacity (Sartori et al., 2001). By contrast, heifers exhibiting 2 follicular waves exhibit a dominant follicle with ovulatory capacity at this time (Ginther et al., 1996) and would not exhibit premature estrus and ovulation due to the presence of $\mathrm{P}_{4}$ from a GnRH-induced CL.

Interval to first $\mathrm{AI}$ was greater $(P<0.01)$ for TC than for GPG heifers with $45.8 \%$ (81/177) of TC heifers and $100.0 \%$ (175/175) of GPG heifers receiving first AI by d 8 of the AI breeding period (Figure 1, upper panel). All 175 GPG heifers received at least one AI service, whereas $2.8 \%$ (5/177) of TC heifers did not receive an AI service during the 42-d AI breeding period (Figure 1, upper panel). Despite the reduced time to first AI, survival time to pregnancy during the 42 -d AI breeding period (Figure 1, lower panel) did not differ $(P=0.65)$ between treatments. By the end of the 42-d AI breeding period, 58.2\% (103/177) of TC heifers had become pregnant compared with $63.4 \%$ (111/175) of GPG heifers (Table 3).

The frequency distributions for the number of heifers receiving second and third AI, during the 42-d AI breeding period are shown in Figure 2. Mean days to first AI was greater $(P<0.01)$ for TC than for GPG heifers $(9.9 \pm 0.6$ vs. $7.5 \pm 0.01 \mathrm{~d})$. In the present study, the GPG protocol was initiated on the first day of the AI breeding period and all heifers in this group were inseminated by $\mathrm{d} 8$. Under these management conditions, heifers not conceiving to TAI are likely to display estrus and receive a second AI by d 19 to 24 after TAI. Because 


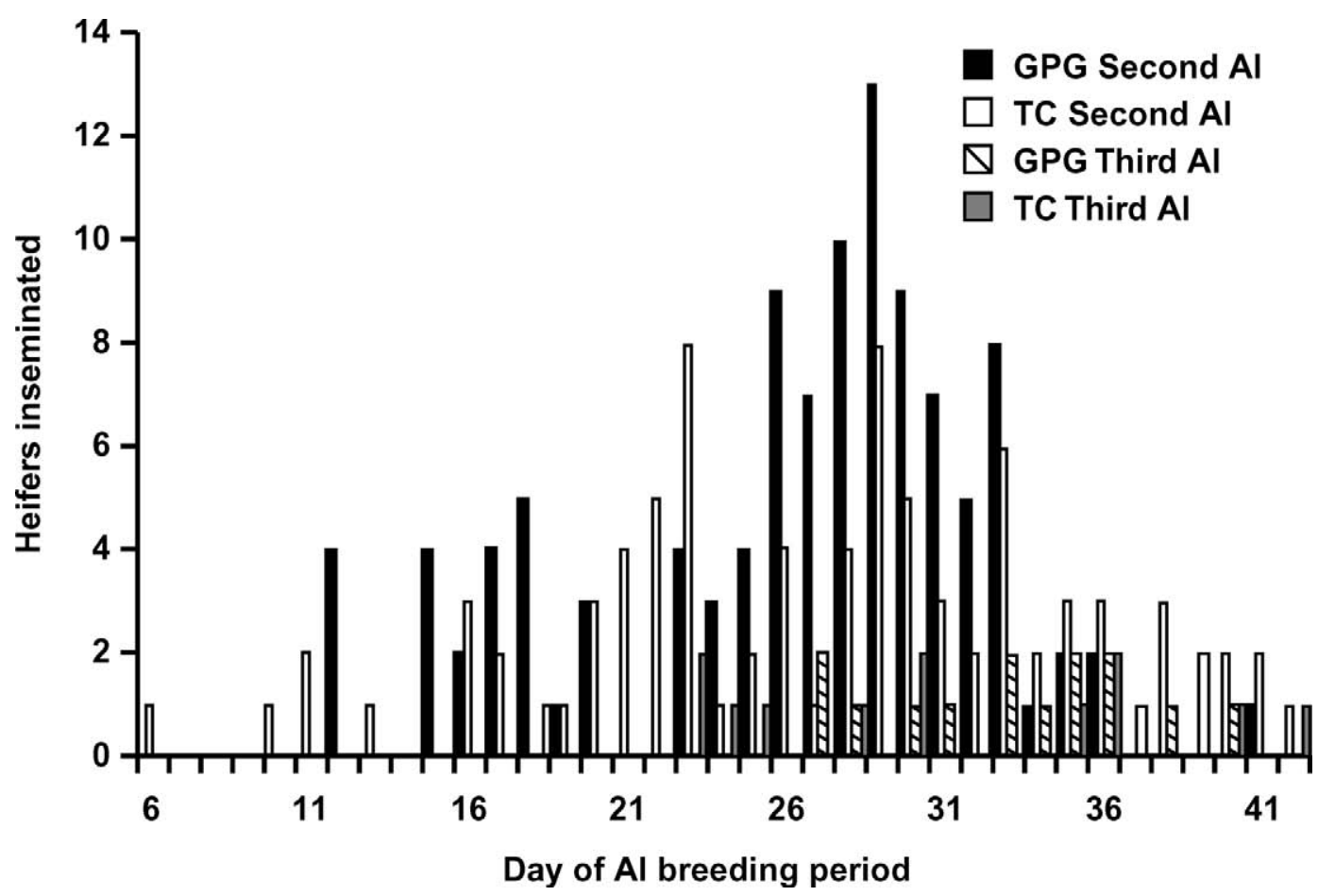

Figure 2. Frequency distribution for heifers receiving second or third AI services. Heifers were randomly assigned to receive either synchronization of ovulation and timed AI and AI after removed tail chalk for the entire AI breeding period (GPG; $\mathrm{n}=175)$, or AI after removed tail chalk for the entire AI breeding period (TC; $n=177$ ). Day 8 of the AI breeding period $=$ TAI for GPG heifers.

average estrous cycle duration in dairy heifers is $22 \mathrm{~d}$ (Sartori et al., 2004), TC heifers on d 0 or 1 of the estrous cycle at the breeding period onset likely would not have the opportunity for a second AI service during the 42$\mathrm{d}$ AI breeding period. Thus, not only is less time needed for estrus detection, but service rate is also increased in GPG heifers for both first and second AI, and the frequency distributions of second and third AI illustrate these trends (Figure 2).

Overall, $8.3 \%$ of pregnant heifers $(7.3 \%, 6 / 82$ of TC heifers and 9.1\%, 10/109 of GPG heifers) mistakenly received an AI service based on tail chalk removal after first AI but before pregnancy diagnosis at $\sim 30 \mathrm{~d}$ after first AI. This was based on the age of the fetus assessed using ultrasonography at pregnancy diagnosis and the time intervals elapsing between the first and second recorded AI services. The $8.3 \%$ error rate in $\mathrm{AI}$ for repeat services agrees with the $91.8 \%$ accuracy we reported for heifers submitted for first AI (Table 2). Artificial insemination during pregnancy has been thought to induce pregnancy loss either through mechanical trauma to fetal membranes or the introduction of infection into the uterine environment (Noakes et al., 2001). Macmillan et al. (1977) reported that an unnecessary reinsemination during diestrus reduced the PR to a previous insemination at the correct time by over $30 \%$.
In the present study, mistaken AI services cannot fully account for pregnancy loss because only $20 \%(3 / 15)$ of the heifers experiencing loss received AI after first AI but before pregnancy diagnosis.

\section{GPG Heifers with High Progesterone on d 8}

Heifers with high $\mathrm{P}_{4}$ on d 8 failed to synchronize luteal function in response to the GPG protocol. Overall, the proportion of heifers with high $\mathrm{P}_{4}$ on $\mathrm{d} 8$ was only $2.7 \%$ (4/144), and $75 \%$ of these heifers ovulated after the second GnRH injection (Table 1). The observation that one of the 4 heifers with high $\mathrm{P}_{4}$ on d $8(2.7 \mathrm{ng} / \mathrm{mL})$ was diagnosed pregnant at $30 \mathrm{~d}$ after TAI illustrates the limitation of this $\mathrm{P}_{4}$ classification scheme for defining reproductive function.

Heifers in the HHH and LHH classes likely had a functional $\mathrm{CL}$ at the time of $\mathrm{PGF}_{2 \alpha}$ treatment that failed to regress in response to $\mathrm{PGF}_{2 \alpha}$ treatment. Incomplete luteal regression, defined as serum $\mathrm{P}_{4}$ concentration $>$ $2.0 \mathrm{ng} / \mathrm{mL} 48 \mathrm{~h}$ after $\mathrm{PGF}_{2 \alpha}$, occurred in $7 \%$ of lactating dairy cows receiving Ovsynch (Moreira et al., 2001). Rivera and Fricke (2002) reported 20\% incomplete luteal regression in dairy heifers when $\mathrm{PGF}_{2 \alpha}$ was given $6 \mathrm{~d}$ after $\mathrm{GnRH}$, as evaluated by blood samples collected every $24 \mathrm{~h}$ after treatment with $\mathrm{PGF}_{2 \alpha}$. In dairy heifers, 
CL are responsive to $\mathrm{PGF}_{2 \alpha}$ at an earlier stage of the estrous cycle compared with lactating cows (Momont and Seguin, 1984). This observation supports our strategy to decrease the interval between $\mathrm{GnRH}$ and $\mathrm{PGF}_{2 \alpha}$ from 7 to $6 \mathrm{~d}$ to adjust for the more rapid turnover of follicular waves in dairy heifers compared with lactating cows (Pursley et al., 1997). No heifers with high $\mathrm{P}_{4}$ on $\mathrm{d} 8$ displayed either the HLH or LLH profiles. These $\mathrm{P}_{4}$ classes likely represent heifers that initiated the first GnRH injection during late diestrus or proestrus of the estrous cycle, which would have received AI after removed tail chalk during the GPG protocol in the present study.

\section{GPG Heifers with Low Progesterone on d 8}

Heifers with low $\mathrm{P}_{4}$ on $\mathrm{d} 8$ lacked a functional CL at the second GnRH injection, and these $\mathrm{P}_{4}$ classes included heifers that were successfully synchronized by the GPG protocol. Of the 144 heifers assigned to a $\mathrm{P}_{4}$ class, $97.2 \%(140 / 144)$ had low $\mathrm{P}_{4}$ on $\mathrm{d} 8$ (Table 1 ). The rate of luteal regression in these heifers was $91.4 \%$ (128/140), ovulation rate to the second GnRH injection was $91.4 \%$ (128/140), and the double ovulation rate for the heifers that ovulated after GnRH was 5.5\% (7/128). Overall, 83.6\% (117/140) of these heifers synchronized follicular and luteal function, resulting in a PR/AI of $38.6 \%$ (Table 1).

No heifers were classified into the LLL profile, indicating that all heifers ovulated before or during the protocol. The 12 heifers in the HLL class were likely in late diestrus or early proestrus at initiation of the GPG protocol similar to HLH and LLH heifers, and some of these heifers may have been in estrus during the protocol but were not detected with removed tail chalk. Furthermore, 33.3\% (4/12) of these heifers were diagnosed pregnant $30 \mathrm{~d}$ after TAI. One objective of this protocol was to induce heifers to have a functional $\mathrm{CL}$ at $\mathrm{PGF}_{2 \alpha}$ treatment and a follicle with ovulatory capacity $2 \mathrm{~d}$ later at the second $\mathrm{GnRH}$ injection. The number of heifers with the desired $\mathrm{P}_{4}$ profile (HHL) was $65.3 \%$ (94/144), expressed as a proportion of the animals receiving TAI (Table 1 ).

Results from the present study suggest that presynchronization of dairy heifers so that initiation of the GPG protocol would coincide with early to mid diestrus may be beneficial. Presynchronization strategies using 2 injections of $\mathrm{PGF}_{2 \alpha}$ have been shown to improve fertility to Ovsynch and TAI in lactating dairy cows (Moreira et al., 2001; Navanukraw et al., 2004). Thus, presynchronization of dairy heifers to reduce or eliminate the HLH, LLH, and HLL profiles may reduce or eliminate the number of heifers in estrus during the protocol, thereby allowing for TAI without estrus detection. In- creasing the proportion of heifers classified as HHL profile may also maximize fertility to TAI. Further research is needed to improve the response of dairy heifers to the GPG protocol reported in the present study.

\section{Effect of Body Size Parameters}

In the present study, heifers were evaluated using both WHI and BCS, to avoid a possible bias due to visual errors in BCS (Looper and Bethard, 2000). Body size parameters and WHI were within body size recommendations by age reported for growing dairy heifers (Hoffman, 1997; Looper and Bethard, 2000) and did not differ for heifers based on pregnancy status $\sim 30 \mathrm{~d}$ after first AI supporting the observation that animal-level factors are not strongly associated with fertility in dairy heifers (Donovan et al., 2003).

\section{Fetal Sex Ratio}

Fetal sex ratio (proportion of females) assessed at d $\sim 75$ of gestation was $50 \%$ for TC heifers vs. $54 \%$ for GPG heifers. By contrast, the sex ratio in a large population of Holstein cattle in Saudi Arabia was skewed toward male for multiparous cows ( $46 \%$ females). Despite the higher number of females fetuses resulting from TAI, fetal sex ratio for pregnancies resulting from TAI did not differ $(P<0.43)$ from the sex ratio of fetuses from heifers receiving AI after removed tail chalk. Increasing the interval from TAI to ovulation in lactating cows has been reported to increase the number of female calves born (Pursley et al., 1998). In addition, heifers in New Zealand that were synchronized had more female calves (53.8\%) compared with untreated control heifers (45.7\%; Xu and Burton, 1999). The mechanism by which this skewing of the sex ratio occurs is not known. In the present study, we assessed fetal gender ratio at $\sim 75$ $d$ of gestation, whereas some of the effects of previous studies may have occurred due to selective survival of females or loss of males during gestation. Further research is needed to assess the effect of timing of AI using the GPG protocol described in the present study on fetal sex ratio in dairy heifers.

\section{CONCLUSION}

The GPG synchronization protocol assessed in the present study can yield acceptable reproductive performance in dairy heifers when estrus detection and AI are performed during the protocol and AI efficiency is optimized. Such a protocol may be useful for dairy producers who wish to breed a group of heifers within an 8-d period and reduce the need for extended periods of estrus detection. Furthermore, use of this protocol will 
concentrate return services for heifers failing to conceive to first AI and may allow for development of systematic resynchronization protocols for submitting heifers for second AI. Expression of estrus during the protocol greatly reduces the synchronization response to the GPG protocol. Hence, future studies should focus on increasing the proportion of heifers receiving TAI and reducing the necessity for estrus detection. Such a strategy may involve hormonal presynchronization to place heifers in an optimal stage of the estrous cycle at the onset of the protocol, or the inclusion of progestin treatment during the protocol to suppress expression of estrus before scheduled TAI.

\section{ACKNOWLEDGMENTS}

We thank Pharmacia Animal Health, for providing Lutalyse and Merial Ltd. for providing Cystorelin for this project. We also thank Jill Colloton for assistance with fetal sex determination. This research was supported by Hatch project WIS04431 to PMF.

\section{REFERENCES}

Barth, A. D. 1993. Factors affecting fertility with artificial insemination. Vet. Clin. North Am. Food Anim. Pract. 9:275-287.

Butler, W. R., and R. D. Smith. 1989. Interrelationships between energy balance and postpartum reproductive function in dairy cattle. J. Dairy Sci. 72:767-783.

Cordoba, M. C., and P. M. Fricke. 2002. Initiation of the breeding season in a grazing-based dairy by synchronization of ovulation. J. Dairy Sci. 85:1752-1763.

Curran, S., and O. J. Ginther. 1991. Ultrasonic determination of fetal gender in horses and cattle under farm conditions. Theriogenology 36:809-814.

Diskin, M. G., and J. M. Sreenan. 1980. Fertilization and embryonic mortality rates in beef heifers after artificial insemination. J. Reprod. Fertil. 59:463-468.

Donovan, G. A., F. L. Bennett, and S. P. Frederick. 2003. Factors associated with first service conception rates in artificially inseminated nulliparous Holstein heifers. Theriogenology 60:67-75

Erven, B. L., and D. Arbaugh. 1987. Artificial insemination on U.S. dairy farms. Report of a study conducted in cooperation with the National Association of Animal Breeders. NAAB, Columbia, MO.

Ferguson, J. D., D. T. Galligan, and N. Thomsen. 1994. Principal descriptors of body condition score in Holstein cows. J. Dairy Sci. 77:2695-2703.

Fricke, P. M. 2002. Scanning the future-Ultrasonography as a reproductive management tool for dairy cattle. J. Dairy Sci. 85:1918-1926.

Fricke, P. M. 2003. Heifer reproduction. Pages 77-82 Raising Dairy Replacements. 1st ed. Midwest Plan Service, Iowa State University, Ames, IA.

Fricke, P. M., J. N. Guenther, and M. C. Wiltbank. 1998. Effect of decreasing the dose of GnRH used in a protocol for synchronization of ovulation and timed AI in lactating dairy cows. Theriogenology 50:1275-1284.

Ginther, O. J., M. C. Wiltbank, P. M. Fricke, J. R. Gibbons, and K. Kot. 1996. Minireview: Selection of the dominant follicle in cattle. Biol. Reprod. 55:1187-1194.

Gwazdauskas, F. C., J. A. Lineweaver, and W. E. Vinson. 1981. Rates of conception by artificial insemination in dairy cattle. J. Dairy Sci. 64:358-362.

Heinrichs, A. J. 1993. Raising dairy replacements to meet the needs of the 21st century. J. Dairy Sci. 76:3179-3187.
Hoffman, P. C. 1997. Optimum body size of Holstein replacement heifers. J. Anim. Sci. 75:836-845.

Looper, M., and G. Bethard. 2000. Management considerations in Holstein heifer development. College of agriculture and home economics-cooperative extension service, Guide B-118, New Mexico State University, Las Cruces.

López-Gatius, F. 1999. Site of semen deposition in cattle: A review. Theriogenology 53:1407-1414.

Lucy, M. C., H. J. Billings, W. R. Butler, L. R. Ehnis, M. J. Fields, D. J. Kesler, J. E. Kinder, R. C. Mattos, R. E. Short, W. W. Thatcher, R. P. Wettemann, J. V. Yelich, and H. D. Hafs. 2001. Efficacy of an intravaginal progesterone insert and an injection of $\mathrm{PGF}_{2 \alpha}$ for synchronizing estrus and shortening the interval to pregnancy in postpartum beef cows, peripubertal beef heifers, and dairy heifers. J. Anim. Sci. 79:982-995.

Macmillan, K. L., E. D. Fielden, and R. Curnow. 1977. Factors influencing A. I. conception rates. VIII. Effects of non-estrus insemination and return patterns after second inseminations. N.Z. J. Exp. Agric. 5:123-127.

Macmillan, K. L., V. K. Taufa, D. R. Barnes, A. M. Day, and R. Henry. 1988. Detecting estrus in synchronized heifers using tail paint and an aerosol raddle. Theriogenology 30:1099-1114.

Momont, H. W., and B. E. Seguin. 1984. Influence of day of estrous cycle on response to $\mathrm{PGF}_{2 \alpha}$ products: Implications for AI programs for dairy cattle. Pages 00-00 in Proc. 10th Int. Congr. Anim. Reprod. and AI, University of Illinois, Urbana-Champaign, IL.

Moreira, F., R. L. de la Sota, T. Diaz, and W. W. Thatcher. 2000a. Effect of day of estrous cycle at the initiation of a timed artificial insemination protocol on reproductive responses in dairy heifers. J. Anim. Sci. 78:1568-1576.

Moreira F., C. Risco, M. F. A. Pires, J. D. Ambrose, M. Drost, M. DeLorenzo, and W. W. Thatcher. 2000b. Effect of body condition on reproductive efficiency of lactating dairy cows receiving a timed insemination. Theriogenology 53:1305-1319.

Moreira, F., C. Orlandi, C. A. Risco, R. Mattos, F. Lopes, and W. W. Thatcher. 2001. Effects of presynchronization and bovine somatotropin on pregnancy rates to a timed artificial insemination protocol in lactating dairy cows. J. Dairy Sci. 84:1646-1659.

Noakes, D. E., T. J. Parkison, and G. C. W. England. 2001. Pages 497-499 in Arthur's Veterinary Reproduction and Obstetrics, 8th ed. Harcourt Publishers Ltd., London, UK.

Navanukraw, C., L. P. Reynolds, J. D. Kirsch, A. T. Grazul-Bilska, D. A. Redmer, and P. M. Fricke. A modified presynchronization protocol improves fertility to timed artificial insemination in lactating dairy cows. J. Dairy Sci. 87:1551-1557.

Odde, K. G. 1990. A review of synchronization of estrus in postpartum cattle. J. Anim. Sci. 68:817-830.

Pursley, J. R., M. O. Mee, and M. C. Wiltbank. 1995. Synchronization of ovulation in dairy cows using $\mathrm{PGF}_{2 \alpha}$ and $\mathrm{GnRH}$. Theriogenology 44:915-923.

Pursley, J. R., M. C. Wiltbank, J. S. Stevenson, J. S. Ottobre, H. A. Garverick, and L. L. Anderson. 1997. Pregnancy rates per artificial insemination for cows and heifers inseminated at a synchronized ovulation or synchronized estrus. J. Dairy Sci. 80:295-300.

Pursley, R. J., R. W. Silcox, and M. C. Wiltbank. 1998. Effect of time of artificial insemination on pregnancy rates, calving rates, pregnancy loss and gender ratio after synchronization of ovulation in lactating dairy cows. J. Dairy Sci. 81:2139-2144.

Rivera, H., and P. M. Fricke. 2002. Synchronization of estrus in dairy heifers using GnRH, PGF $2 \alpha$ and ECP. J. Dairy Sci. 85(Suppl. 1):267. (Abstr.)

Ron, M., R. Bar-Anan, and G. R. Wiggans. 1984. Factors affecting conception rates of Israeli Holstein cattle. J. Dairy Sci. 67:854860.

Roy, G. L., and H. Twagiramungu. 1996. A fixed-time AI program using the GnR-PGF ${ }_{2 \alpha}-\mathrm{GnRH}$ method for beef females. J. Anim. Sci. 74(Suppl. 1):462. (Abstr.)

Salverson, R. R., J. M. DeJarnette, C. E. Marshall, and R. A. Wallace. 2001. Synchronization of estrus in virgin beef heifers using melengestrol acetate and $\mathrm{PGF}_{2 \alpha}$ : An efficacy comparison of cloprostenol and dinoprost tromethamine. Theriogenology 57:853-858. 
Sartori, R., P. M. Fricke, C. P. Ferreira, O. J. Ginther, and M. C. Wiltbank. 2001. Follicular deviation and acquisition of ovulatory capacity in bovine follicles. Biol. Reprod. 65:1403-1409.

Sartori, R., J. M. Haughian, R. D. Shaver, G. J. M. Rosa, and M. C. Wiltbank. 2004. Comparison of ovarian function during the estrous cycle of Holstein heifers and lactating cows. J. Dairy Sci. 87:905-920.

SAS User's Guide: Statistics, Version 6, 4th edition. 1999. SAS Inst., Inc., Cary NC.

Schmitt, E. J. P., T. Diaz, M. Drost, and W. W. Thatcher. 1996. Use of a gonadotropin-releasing hormone agonist or human chorionic gonadotropin for timed insemination in cattle. J. Anim. Sci. 74:1084-1091.
Smith, M. W., and J. S. Stevenson. 1995. Fate of the dominant follicle, embryonal survival, and pregnancy rates in dairy cattle treated with prostaglandin $\mathrm{F}_{2 \alpha}$ and progestins in the absence or presence of a functional corpus luteum. J. Anim. Sci. 73:3743-3751.

Van Amburgh, M. E., D. M. Galton, D. E. Bauman, R. W. Everett, D. G. Fox, L. E. Chase, and H. N. Erb. 1998. Effects of three prepubertal body growth rates on performance of Holstein heifers during first lactation. J. Dairy Sci. 81:527-538.

Xu, Z. Z., and L. J. Burton. 1999. Reproductive performance of dairy heifers after estrus synchronization and fixed-time artificial insemination. J. Dairy Sci. 82:910-917.

Zavy, M. T., and R. D. Geisert. 1994. Pages 3, 5, 109, 111 in Embryonic Mortality in Domestic Species. CRC Press Inc., Boca Raton, FL. 